\title{
How does forest recovery following moderate-severity fire influence effects of subsequent wildfire in mixed-conifer forests?
}

Brandon M. Collins ${ }^{1 *}$, Jamie M. Lydersen², Richard G. Everett ${ }^{2,3}$ and Scott L. Stephens ${ }^{2}$

\begin{abstract}
Background: Given regional increases in fire activity in western North American forests, understanding how fire influences the extent and effects of subsequent fires is particularly relevant. Remotely sensed estimates of fire effects have allowed for spatial portioning into different severity categories based on the degree of fire-caused vegetation change. Fire effects between minimal overstory tree mortality $(<20 \%)$ and complete (or nearly complete) overstory tree mortality (>95\%) are often lumped into a single category referred to as moderate severity. In this paper, we investigated how burned areas in this broad category of moderate-severity fire fared when reburned by a subsequent fire. Specifically, we examined the influence of forest structure, tree species composition, and shrub cover 9-17 yr following moderate-severity fire on the severity of a subsequent large wildfire event. We used plot-based measurements of trees and shrub cover to develop 15 forest structure and composition variables to attempt to explain observed reburn severity.

Results: Only live Abies Mill. species basal area and dead standing biomass were identified as significant predictors of reburn severity using conditional inference tree analysis, both of which were positively related to reburn severity.
\end{abstract}

Conclusion: Our findings emphasize that the wide range of fire effects in the moderate-severity category can contribute to highly variable responses to subsequent wildfire.

Keywords: Departure, Fire exclusion, Forest restoration, Fire suppression, Mixed conifer forest

\footnotetext{
*Correspondence: bcollins@berkeley.edu

${ }^{1}$ Center for Fire Research and Outreach, University of California, Berkeley,

California 94720-3114, USA

Full list of author information is available at the end of the article
} 


\section{Resumen}

Antecedentes: Dados los incrementos regionales en actividades de incendios en bosques de Norteamérica, es particularmente relevante comprender cómo el fuego influencia el alcance y efectos de subsiguientes incendios. La estimación de los efectos del fuego mediante sensores remotos ha permitido la partición espacial en distintas categorías de severidad basada en el grado de cambios en la vegetación causados por el fuego. Los efectos del fuego entre la mortalidad mínima (<20\%) y máxima (> 95\%) de árboles que ocupan el estrato del dosel superior, son frecuentemente agrupados en una única categoría referida como de moderada severidad. En este trabajo investigamos cómo resultan las áreas quemadas en esta amplia categoría de moderada severidad luego de ser afectadas por un incendio posterior. Específicamente, examinamos la influencia de la estructura forestal, la composición específica de árboles, y la cobertura de arbustos, de 9 a 17 años después de un fuego de moderada severidad, sobre la severidad de un evento de incendio de grandes proporciones. Usamos mediciones en parcelas de árboles y cobertura de arbustos para desarrollar 15 estructuras y composiciones variables, en un intento de explicar la severidad del evento del incendio subsiguiente.

Resultados: Sólo el área basal de árboles vivos de las especies Abies Mill., y la biomasa muerta en pié fueron identificados como predictores de la severidad en fuegos subsiguientes usando un análisis de inferencia condicional, dado que ambos fueron relacionados positivamente con la severidad del incendio subsiguiente.

Conclusiones: Nuestros resultados enfatizan que el amplio rango de efectos del fuego en la categoría de moderada severidad puede contribuir a respuestas altamente variables en un incendio subsiguiente.

\section{Background}

The use of remote sensing to assess fire effects on vegetation has allowed for tremendous advancements in characterizing spatial patterns of fire and understanding drivers of fire severity (Key and Benson 2005, Miller and Thode 2007, Parks et al. 2014). In conifer-dominated forests, high-severity fire effects have received considerable attention due to the magnitude of associated ecological change. Based on commonly used thresholds for remotely sensed fire severity (e.g., Relative differenced Normalized Burn Ratio [RdNBR]; thresholds in Miller and Thode (2007)) the high-severity category has been shown to capture complete (or nearly complete) overstory tree mortality (>95\% basal area mortality; Lydersen et al. 2016). The low-severity category, on the other hand, captures post-fire conditions with minimal overstory mortality $(<20 \%$ by basal area). Fire effects between these two extremes are often lumped into a single category referred to as moderate severity. Lydersen et al. (2016) described moderate severity as a "catch all" category that, "captures everything spanning from little overstory change to nearly complete overstory mortality."

Moderate severity has been combined with low severity to characterize fire effects that are likely to restore ecosystem structure and function in mixed-conifer forests in which fire has long been suppressed (North et al. 2012, Mallek et al. 2013). This assertion is based on the reductions in tree densities and surface and ladder fuels associated with low- and moderate-severity fire (Collins et al. 2011, Becker and Lutz 2016). This is supported by findings from Lydersen et al. (2017) that demonstrated that low- and moderate-severity fire improves landscape resilience to subsequent wildfire. However, labeling such a range of fire effects as uniformly "restorative" ignores a couple of important distinctions between low and moderate severity. First, low-severity fire typically does not affect mid-sized or large tree density (Collins et al. 2011, Collins et al. 2017). In productive forests with long periods of fire exclusion, there can be considerable increase in shade-tolerant mid-sized trees relative to historical conditions, which results in greater overall canopy cover and fewer canopy openings (Lydersen et al. 2013, Fry et al. 2014, Knapp et al. 2017). These increases not only impact shade-intolerant tree regeneration, but forest understory plant species composition as well (Zald et al. 2008, Knapp et al. 2013). Moderate severity fire can result in significant reductions in live tree density, including mid-sized trees, and the creation of small canopy openings (Lydersen et al. 2016, Huffman et al. 2017). Both Lydersen et al. (2016) and Huffman et al. (2017) demonstrated that average live tree basal area and tree density following moderate-severity fire were within the historical range of variability for their respective landscapes. Furthermore, Lydersen et al. (2016) demonstrated that moderate-severity fire favored survival of pines over shade-tolerant species, which is a common objective for restoration of forests that have experienced long priods of fire exclusion (North et al. 2009).

The second important distinction between low and moderate severity is in the distribution of biomass between live and dead pools. Although both severity levels have been shown to reduce live tree densities, much of the fire-killed biomass remains on site (Eskelson et al. 2016), shifting from a state of relatively high fuel 
moisture (live) to one of low fuel moisture (dead) (Fig. 1). Since moderate severity is associated with greater live tree density reductions, there is likely greater dead tree biomass following fire compared to low severity. These dead trees generally remain standing for several years following fire but, over time, fall and become part of the surface-fuel pool. The reduction in canopy cover associated with moderate-severity fire, combined with the consumption of surface and ground fuel (exposing mineral soil) can also allow for a robust shrub and tree regeneration response in the understory (Fig. 2), which further adds to the surface-fuel pool. These overstory and understory dynamics following moderate-severity fire likely influence the behavior and effects of subsequent wildfire. However, given the wide range in forest structural change associated with moderate-severity fire, it may be difficult to develop broadly applicable predictions of how fuel dynamics in these areas will influence burning in subsequent fires. From a land management standpoint, this may create a dilemma because moderate-severity fire has been shown to restore live forest structure (Collins et al. 2017, Huffman et al. 2017); however, the vegetation and fuel responses following moderate-severity fire may compromise resilience to subsequent wildfire.

In this study, we took advantage of a unique opportunity to investigate how burned areas in this broad category of moderate-severity fire fared when reburned by a subsequent fire. Our specific objective was to examine the influence of forest structure, tree species composition, and shrub cover 9-17 yr following moderate-severity fire on

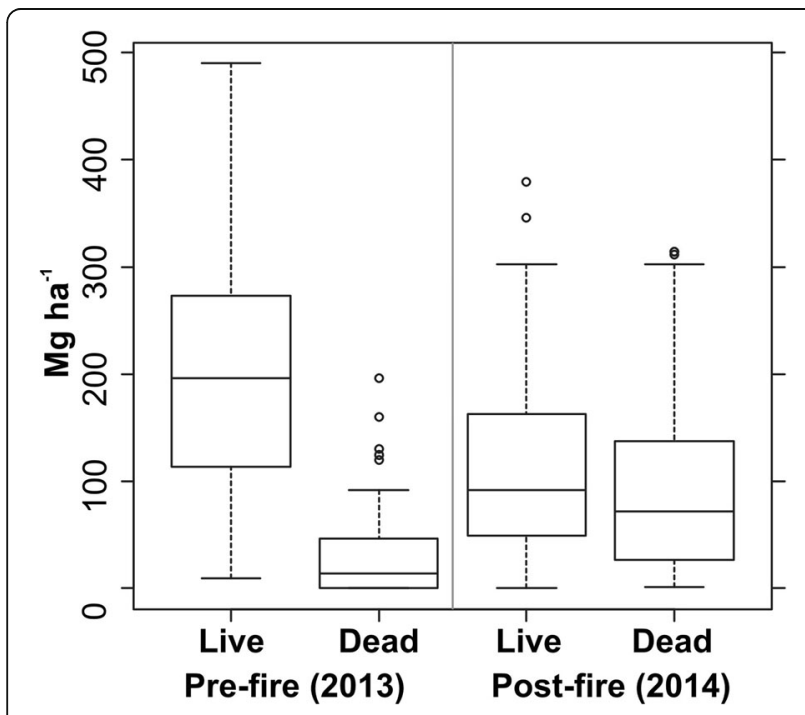

Fig. 1 Standing-tree biomass immediately before and one year after moderate severity-fire in the 2013 Rim Fire. These biomass estimates are from 66 field plots, which is a subset of the data presented in Lydersen et al. (2016). Biomass estimates were based on the allometric equations presented in Jenkins et al. (2004) the severity of a subsequent large wildfire event. Although we had additional field plots that initially burned at low severity and subsequently reburned, this study focused only on those initially burned at moderate severity. This was done because of an overall lack of information specific to moderate-severity fire effects in the existing literature and the relatively recent interest in moderate-severity fire for forest restoration and management.

\section{Methods}

The field plots used in the analysis spanned portions of the Stanislaus National Forest (NF) and Yosemite National Park (NP) in the central Sierra Nevada, California, USA (Fig. 3). Plot elevations ranged from 1436 to $1845 \mathrm{~m}$ (mean $1546 \mathrm{~m}$ ). These field plots were established for a study that investigated forest change based on a historical forest inventory (Collins et al. 2017), but for the present study we focused on the contemporary data and the fire effects these areas experienced following plot establishment. The study area is characterized as lower montane Sierra Nevada mixed-conifer, consisting of sugar pine (Pinus lambertiana Dougl.), ponderosa pine (P. ponderosa Lawson \& C. Lawson), white fir (Abies concolor [Gord. \& Glend.] Lindl.), incense-cedar (Calocedrus decurrens [Torr.] Florin), and Douglas-fir (Pseudotsuga menziesii [Mirb.] Franco) (North et al. 2016). Common understory shrub species in the study area include Chamaebatia foliolosa Benth., which is short in stature $(<0.5 \mathrm{~m})$, and a few taller-stature species: Ceanothus integerrimus Hook. \& Arn., Arctostaphylos patula Greene, and Ribes roezlii Regel. Climate consists of generally cool, wet winters and warm, dry summers. Annual precipitation is a mixture of rain and snow, which averages $50-60 \mathrm{~cm} \mathrm{yr}^{-1}$. Mean monthly temperatures range from $4{ }^{\circ} \mathrm{C}$ in January to $20^{\circ} \mathrm{C}$ in July (Crane Flat Remote Automated Weather Station, 1992-2016, approximately $10 \mathrm{~km}$ south of the study area). Prior to 1900, low- to moderate-severity fire was common in this area, with a mean point fire return interval of $12 \mathrm{yr}$ (Scholl and Taylor 2010).

Placement of field plots was based on a prior study (Collins et al. 2017), for which three to four 0.1 ha circular plots (radius $17.8 \mathrm{~m}$ ) were centered at random, non-overlapping distances along centerlines of quarter-quarter sections in the Public Land Survey System. In each plot, we recorded tree species, height, and diameter at breast height (dbh) for all trees $5.1 \mathrm{~cm}$ $\mathrm{dbh}$ and greater. In addition, we recorded shrub cover by species (ocular estimate), aspect, and slope at each plot. We did not collect information on dead and downed surface fuels. The decision to forego these measurements was primarily because comparable surface fuel measurements were lacking in the historical inventory data. Contemporary plot measurements were spread out across three non-consecutive years: 2005, 2007, and 

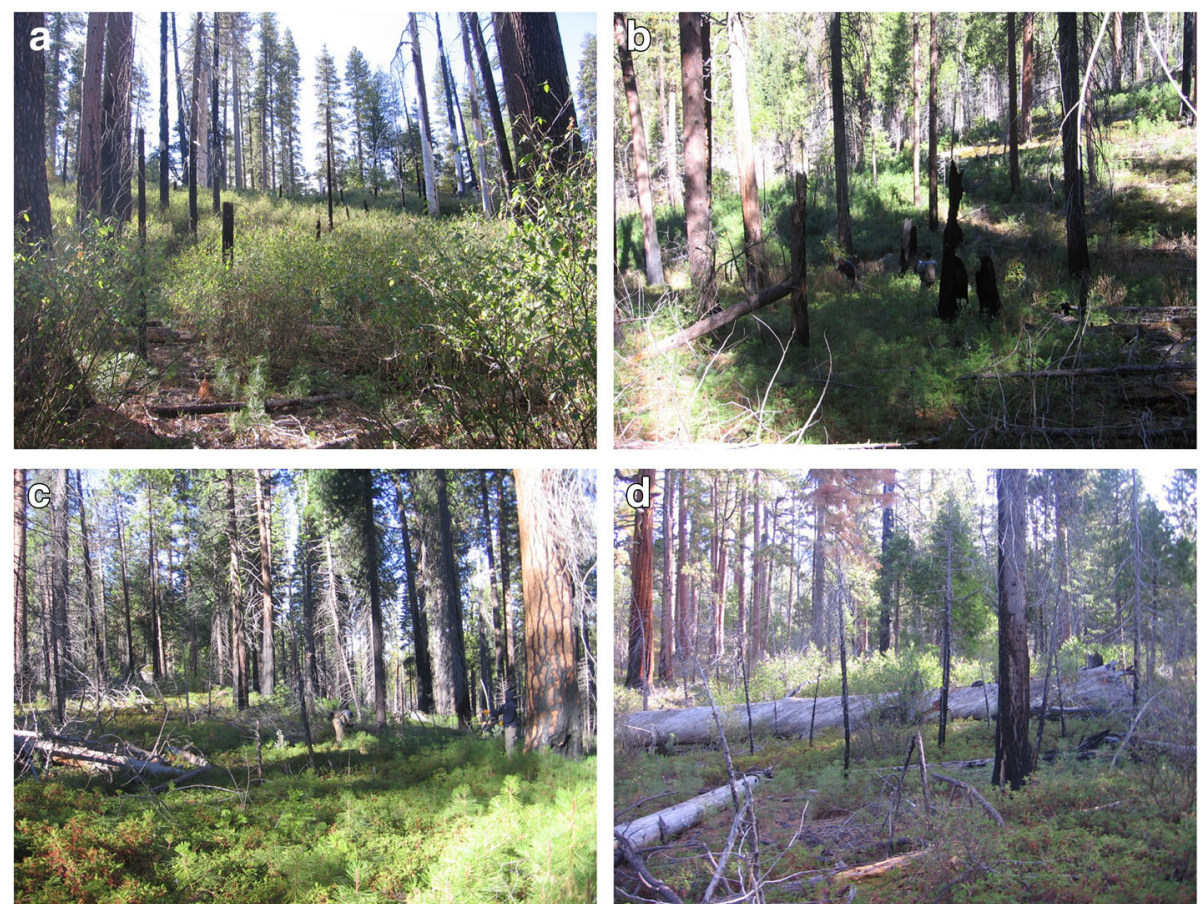

Fig. 2 Photographs from field plots demonstrating different overstory and understory dynamics nine years after moderate-severity fire: (a) high cover of tall shrubs, mainly Ceanothus L. species, with moderate levels of standing and downed fire-killed snags; (b) prolific tree seedling establishment with relatively high levels of standing and downed fire-killed snags; (c) mixture of low-stature shrubs and tree seedlings occupying nearly the entire forest floor, moderate levels of standing and downed fire-killed snags; and (d) moderate cover of low-stature shrubs with high levels of downed fire-killed snags.

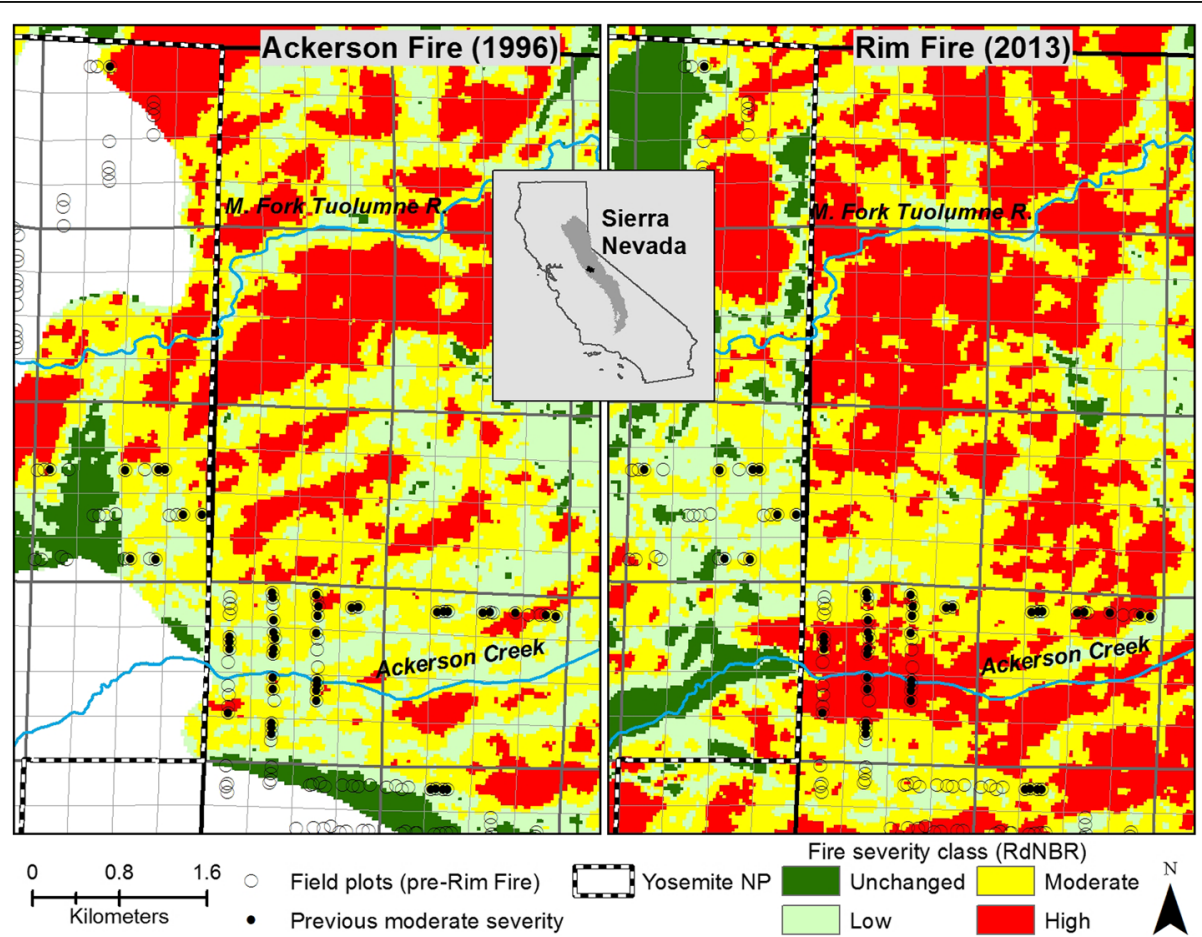

Fig. 3 Fire severity classification, based on the Relative differenced Normalized Burn Ratio (RdNBR), for the initial fire (Ackerson Fire, 1996) and reburn (Rim Fire, 2013) affecting the 47 field plots analyzed in this study (filled black circles). These field plots were measured between 2005 and 2013, which is 9-17 yr following the initial fire, and 0-8 yr prior to the reburn. These plots are a subset of those analyzed in Collins et al. (2017). 
2013. The 2005 and 2007 measurements focused on Yosemite NP; additional funding allowed for expanding re-measurement to the Stanislaus NF in 2013.

Two large wildfires affected our study area-one burned prior to field-plot establishment (1996 Ackerson Fire) and the other following plot establishment (2013 Rim Fire). Based on comprehensive fire perimeter datasets collated by Yosemite NP and California Department of Forestry and Fire Protection (http://frap.fire.ca.gov/ data/frapgisdata-sw-fireperimeters_download), there was very little additional fire activity within and around these plots (one plot with a fire in 1914 and one on the edge of a 2011 fire). Severity of both fires was estimated with RdNBR, which was derived from Landsat Thematic Mapper imagery acquired the year of and one year following each fire (Fig. 3). Given the focus on moderate severity, we only included field plots that had RdNBR values from the Ackerson Fire between 315 and 640 (moderate-severity class thresholds from Miller and Thode (2007)). This resulted in a total of 47 plots across 19 quarter-quarter sections (Fig. 3). RdNBR values for each plot were extracted from $30 \mathrm{~m}$ resolution raster data using bilinear interpolation, which weights values of the four nearest pixels based on distance to plot center.

We generated the following forest stand structure and composition variables using data collected in the field plots: live basal area by species, live and dead standing tree biomass using equations in Jenkins et al. (2004), live and dead standing tree density, live tree density by dbh class (5.1-15.1, 15.2-30.4, 30.5-61.0, 61.1-91.4, > 91.4 cm), and shrub cover separated into two classes based on height $(<0.5$ and $\geq 0.5 \mathrm{~m})$. We used a two-stage approach to explore the influence of these potential explanatory variables on the severity, as captured by RdNBR, in the 2013 Rim
Fire. First, we used a random forest analysis to identify influential explanatory variables and rank their importance. We used the "cforest" function in the PARTY package (Hothorn et al. 2009) for R statistical computing software (R Development Core Team 2014), with 1000 individual regression trees and the default setting of five variables per regression tree. We used conditional permutation importance measures to identify the most influential predictor variables. These variables were used to run our second stage of analysis, a conditional inference tree. By only including influential predictor variables identified from the random forest analysis, we attempted to minimize potentially spurious results that tree-based analyses can be prone to. This analysis was performed using the "ctree" function, which is also in the PARTY package (Hothorn et al. 2009). This approach identifies influential explanatory variables using a partitioning algorithm that is based on the lowest statistically significant $P$-value derived from permutation tests. By doing this, it avoids overfitting and biased selection among covariates (Hothorn et al. 2006). A significance level of 0.05 was used in assessing all splits. Goodness-of-fit was assessed by calculating a pseudo $\mathrm{R}^{2}$ as 1 minus the quotient of residual variance divided by total variance.

\section{Results}

Four of the total 15 forest structure and composition variables had noticeably greater relative importance in explaining observed Rim Fire severity (Fig. 4a, Table 1). These four variables were live white fir basal area, live tree density for trees $30.6-61.0 \mathrm{~cm}$ dbh, dead standing biomass, and total live tree density. The other 11 variables had very little influence on Rim Fire severity (Fig. 4a). Of those top four variables, only white fir basal area and dead standing biomass were identified as
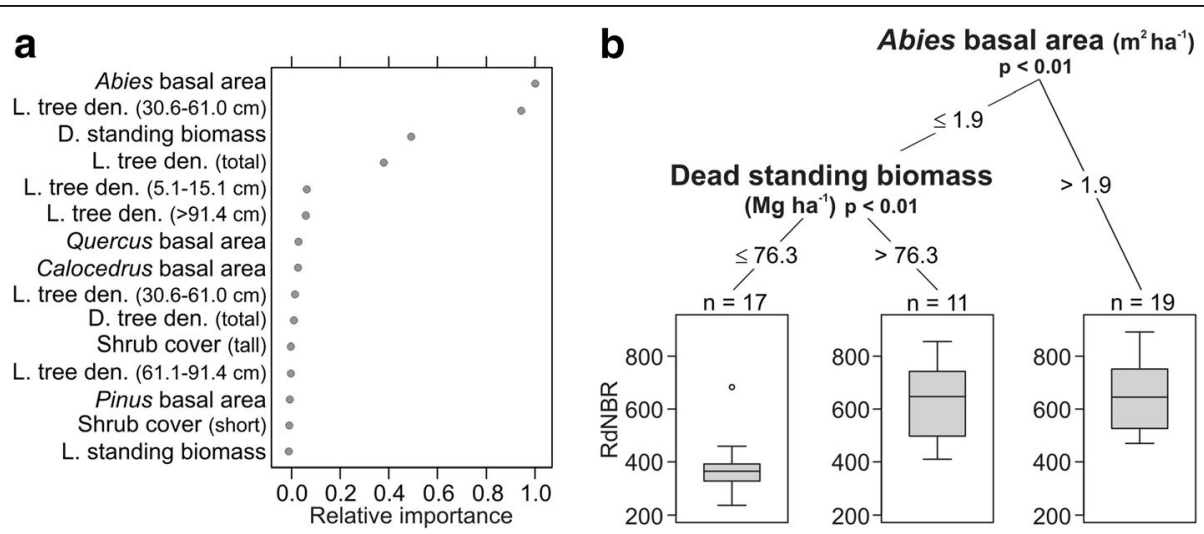

Fig. 4 Random forest (a) and conditional inference tree (b) analysis output explaining the influence of forest structure and composition variables on the Relative differenced Normalized Burn Ratio (RdNBR) for field plots burned in the 2013 Rim Fire. Variables are listed in descending order according to their relative importance (a). Abbreviations are: $\mathrm{L} .=$ live, $\mathrm{D} .=$ dead, den. $=$ density, and $\mathrm{cm}=$ centimeters diameter at breast height. Of the top four most important variables, only two were identified as significant in the conditional inference tree analysis (b). $P$-values at each node are from permutation tests with a Bonferroni adjustment. Number of field plots $(n)$ and box plots showing the distribution of RdNBR values in the 2013 Rim Fire for resulting groups of field plots are shown at each terminal node. The pseudo $R^{2}$ for the tree is 0.52 
Table 1 Summary statistics for field plots $(n=47)$, which includes fire severity, based on the Relative differenced Normalized Burn Ratio (RdNBR), and the top four forest structure or composition variables explaining observed variability in Rim Fire RdNBR (see Methods section)

\begin{tabular}{llll}
\hline & Mean & Median & Range \\
\hline 1996 Ackerson Fire RdNBR & 427 & 389 & $319-627$ \\
2013 Rim Fire RdNBR & 545 & 523 & 237-890 \\
Live tree density, $15.2-30.5{\mathrm{~cm} \mathrm{dbh}\left(\mathrm{ha}^{-1}\right)}$ & 68.1 & 40.0 & $0-280$ \\
Abies basal area $\left(\mathrm{m}^{2} \mathrm{ha}^{-1}\right)$ & 2.5 & 0.2 & $0-11.6$ \\
Total live tree density $\left(\mathrm{ha}^{-1}\right)$ & 220 & 200 & $0-740$ \\
Dead standing biomass $\left(\mathrm{Mg} \mathrm{ha}^{-1}\right)$ & 96.1 & 68.3 & $0-703$ \\
\hline
\end{tabular}

significant predictors in the conditional inference tree analysis (Fig. 4b). The threshold for white fir basal area associated with higher Rim Fire severity was relatively low, $1.9 \mathrm{~m}^{2} \mathrm{ha}^{-1}$. Field plots exceeding this white fir basal area (40\% of plots) experienced predominantly high-severity fire effects, while severity of those below this threshold depended on the level of standing dead tree biomass (Fig. 4b). Field plots with $\leq 1.9 \mathrm{~m}^{2} \mathrm{ha}^{-1}$ of white fir basal area and $\leq 76.3 \mathrm{Mg} \mathrm{ha}^{-1}$ of dead standing biomass (36\% of plots) tended to burn again at moderate severity (Fig. 4b). Field plots with low white fir basal area but high dead standing biomass ( $24 \%$ of plots) tended to burn at high severity, having a similar distribution of RdNBR values as that for plots with $>1.9 \mathrm{~m}^{2} \mathrm{ha}^{-1}$ white fir basal area (Fig. 4b). The pseudo $\mathrm{R}^{2}$ for the conditional inference tree was 0.52 .

\section{Discussion}

There is growing understanding regarding the need to significantly expand fire use to manage vegetation and fuels in drier North American forest types (Calkin et al. 2015, North et al. 2015, Parks et al. 2015, Stephens et al. 2016). This need is based on the notions that 1) fire has been an integral ecological process for thousands of years and, without it, these forests lose key structures and function (Stephenson 1999); and 2) relatively frequent low- to moderate-severity fire reduces the potential for uncharacteristically large patches of stand-replacing fire (Larson et al. 2013, Harris and Taylor 2017, Lydersen et al. 2017). While there is a strong basis for both of these assertions in the existing literature, there is a need to better understand the mechanisms of how low- to moderate-severity fire influences subsequent wildfire. This is particularly the case for forests that have long experienced fire exclusion and carry a legacy (in biomass) of fire deficit and past timber harvesting (Brown et al. 2008, Knapp et al. 2013, Taylor et al. 2014, Collins et al. 2017). In these forests, low- to moderate-severity fire clearly consumes surface and ladder fuels, which reduces potential behavior and effects of subsequent fire (Agee and Skinner 2005).
However, it also possible that vegetation and fuel dynamics over time could increase subsequent fire behavior and effects (Coppoletta et al. 2016, Stevens-Rumann and Morgan 2016). Our results provide some insight as to how longer-term vegetation dynamics following initial fire (i.e., after a long period of fire exclusion) influence effects in a subsequent large wildfire. This is relevant because reburning by large wildfires is becoming more common in dry western North American forests (Prichard et al. 2017), which could only be expected to increase as fire use, and wildfire activity as a whole, increase into the future.

Our findings indicating that higher reburn severity in areas that had even modest levels of white fir basal area or high levels of standing dead biomass fit with expectations on how both variables influence fire behavior. White fir is often described as a fire-sensitive species (North et al. 2016), in that it does not have common fire-tolerant characteristics (i.e., thick bark when young, insulated buds, self pruning). One explanation for the higher reburn severity is that the initial moderate-severity fire injured but did not kill the white fir trees in the overstory canopy, and then the reburn ultimately killed these weakened trees; we do not have post-fire field data from these plots to corroborate this. Another explanation is that white fir basal area is positively related to woody surface fuel loads (Fry and Stephens 2010, Lydersen et al. 2015), which could have contributed to higher surface-fire intensity. The higher surface-fire intensity, in combination with lower fire tolerance, may have led to greater overstory mortality. Note that the term fire intensity, which is a physical measurement of energy released from flaming combustion, is different from fire severity, which, in our case, reflects the effect of fire on vegetation (Keeley 2009). The association between greater standing dead biomass and higher fire severity, independent of white fir abundance, is a fairly straightforward interpretation. Greater biomass of standing dead trees is also related to higher total surface fuel loads (Lydersen et al. 2015), thus likely causing higher surface fire intensity and perhaps torching.

It was interesting that shrub cover was not an important explanatory factor for reburn severity. Previous work has demonstrated that greater shrub cover following initial fires can lead to higher reburn severity (Coop et al. 2016, Coppoletta et al. 2016). One explanation for this lack of shrub importance in our findings is that shrub cover in our plots was not as high as in areas initially burned at high severity. Mean tall- and short-stature shrub cover from our field plots was $28 \%$ and $22 \%$, respectively. It is possible that, at these levels, there was enough discontinuity in shrub cover that they did not exacerbate surface-fire intensity in the reburn. Observations from this study area support this assertion (R. Everett, University of California, Berkeley, USA, unpublished data). It is unlikely that this discontinuity was 
simply a product of insufficient time given the strong post-fire establishment response that the dominant shrub species have (USDA Forest Service 2018) and the relatively long period between initial and reburn fires $(17 \mathrm{yr})$. Rather, the presence (and spatial pattern) of live overstory trees following initial fire likely influenced the total proportion and pattern of shrub cover. Further investigation into the influence of live overstory on post-fire shrub establishment and growth would be needed to fully test this linkage.

Our findings have a few important limitations worth noting. First, the fact that we only examined field plots that initially burned at moderate severity limits the inference that can be drawn. As we stated previously, this decision to focus on moderate severity was driven by an overall lack of existing information on moderate-severity fire effects in these forest types. Second, since dead and downed surface fuel information was not collected in our plots, we are potentially missing an important contributor to fire behavior, and ultimately to observed fire effects. As a result, our findings may not fully capture how fuel dynamics following initial moderate-severity fire affect the severity in a subsequent reburn. Lastly, our relatively small sample size, 47 field plots, all of which burned in the same two fire events, is an additional limitation. Ideally we would have liked to have more field plots across a broader geographic region to allow for broader inferences across mixed-conifer forest. On the other hand, because our field observations captured a longer-term response following the initial fire (9-17 yr, mean $12 \mathrm{yr}$ ), we feel that these findings may be particularly relevant for understanding how vegetation dynamics following fire influence future reburns. This is an important aspect that is generally lacking in existing studies, which tend to focus more on shorter-term responses following fire and other silvicultural treatments.

\section{Conclusions}

Our findings emphasize that the wide range of fire effects in the moderate-severity category can contribute to highly variable responses to subsequent wildfire. One possible way to address this uncertainty is to refine the moderate-severity category for RdNBR-based classifications by adding a class. This additional class would split the current moderate-severity class in two, which would possibly allow for separating fire-caused mortality of individual overstory trees from that of small groups of overstory trees. We recognize that simply adding more classes does not necessarily result in more precise estimates of fire-caused vegetation change. However, the large error in the current moderate severity class (Miller et al. 2009) suggests that splitting the class could improve connections to on-the-ground measurements.
Moderate-severity fire has been shown to be an effective tool for restoring forest structure in forests that have experienced long periods of fire exclusion (Collins et al. 2017; Huffman et al. 2017). Beyond achieving restoration objectives, the tree density reductions and heterogeneity introduced by moderate-severity fire may allow these forests to adapt to increases in temperature and drought frequency (Williams et al. 2010; Williams et al. 2015). However, the uncharacteristic accumulation of biomass in forests that have experienced long periods of fire exclusion leaves a legacy that is not eliminated with a single fire. An approach to improving resilience in forests with high levels of accumulated biomass may be to capitalize on the initial work achieved with moderate-severity fire by using prescribed fire to consume some of the dead biomass resulting from the initial fire. This may be a particularly effective strategy given the projected increases in regional wildfire activity (Westerling et al. 2011).

\section{Acknowledgements \\ E. Gasarch, C. Caruso, G. Roller, J. Dvorak, B. Tracy, E. Fales, C. Richter, B. Weise, and K. King assisted in field data collection and we thank them for their hard work.

\begin{abstract}
Funding
Funding was provided by NPS Pacific West Region and the UC Agriculture and Natural Resources Division. This work was also supported by a research partnership between the US Forest Service Pacific Southwest Research Station
\end{abstract} and UC Berkeley College of Natural Resources (project no. 16-JV-11272167-063).}

Availability of data and materials

Please contact author for data requests.

Authors' contributions

B. Collins, J. Lydersen, R. Everett, and S. Stephens all conceived of this study. B. Collins and J. Lydersen did the data analysis. B. Collins, J. Lydersen, R. Everett, and S. Stephens contributed to the writing of the paper. All authors read and approved the final manuscript

Ethics approval and consent to participate Not applicable.

Consent for publication

Not applicable.

Competing interests

The authors declare that they have no competing interests.

\section{Publisher's Note}

Springer Nature remains neutral with regard to jurisdictional claims in published maps and institutional affiliations.

\section{Author details}

${ }^{1}$ Center for Fire Research and Outreach, University of California, Berkeley, California 94720-3114, USA. ${ }^{2}$ Ecosystem Sciences Division, Department of Environmental Science, Policy, and Management, University of California, Berkeley, California 94720, USA. ${ }^{3}$ Department of Natural Resources, Salish Kootenai College, 58138 Highway 93, Pablo, Montana 59855, USA. 
Received: 8 June 2018 Accepted: 3 July 2018

Published online: 30 August 2018

\section{References}

Agee JK, Skinner CN (2005) Basic principles of forest fuel reduction treatments. Forest Ecology and Management 211(1-2):83-96 https://doi.org/10.1016/j. foreco.2005.01.034

Becker KML, Lutz JA (2016) Can low-severity fire reverse compositional change in montane forests of the Sierra Nevada, California, USA? Ecosphere 7(12): e01484 https://doi.org/10.1002/ecs2.1484

Brown PM, Wienk CL, Symstad AJ (2008) Fire and forest history at Mount Rushmore. Ecological Applications 18(8):1984-1999 https://doi.org/10.1890/ 07-1337.1

Calkin DE, Thompson MP, Finney. MA (2015) Negative consequences of positive feedbacks in US wildfire management. Forest Ecosystems 2(1):9 https://doi. org/10.1186/s40663-015-0033-8

Collins BM, Everett RG, Stephens SL (2011) Impacts of fire exclusion and managed fire on forest structure in an old growth sierra Nevada mixedconifer forest. Ecosphere 2(4):51 https://doi.org/10.1890/ES11-00026.1

Collins BM, Fry DL, Lydersen JM, Everett R, Stephens SL (2017) Impacts of different land management histories on forest change. Ecological Applications 27(8):2475-2486 https://doi.org/10.1002/eap.1622

Coop JD, Parks SA, McClernan SR, Holsinger LM (2016) Influences of prior wildfires on vegetation response to subsequent fire in a reburned Southwestern landscape. Ecological Applications 26(2):346-354 https://doi. org/10.1890/15-0775

Coppoletta M, Merriam KE, Collins BM (2016) Post-fire vegetation and fuel development influences fire severity patterns in reburns. Ecological Applications 26(3):686-699 https://doi.org/10.1890/15-0225

Eskelson BNI, Monleon VJ, Fried JS (2016) A 6 year longitudinal study of post-fire woody carbon dynamics in California's forests. Canadian Journal of Forest Research 46(5):610-620 https://doi.org/10.1139/cjfr-2015-0375

Fry DL, Stephens SL (2010) Stand-level spatial dependence in an old-growth Jeffrey pine-mixed conifer forest, Sierra San Pedro Mártir, Mexico. Canadian Journal of Forest Research 40:1803-1814 https://doi.org/10.1139/X10-122

Fry DL, Stephens SL, Collins BM, North M, Franco-Vizcaíno E, Gill SJ (2014) Contrasting spatial patterns in active-fire and fire-suppressed mediterranean climate old-growth mixed conifer forests. PLoS ONE 9(2):e88985 https://doi. org/10.1371/journal.pone.0088985

Harris L, Taylor AH (2017) Previous burns and topography limit and reinforce fire severity in a large wildfire. Ecosphere 8(11):e02019 https://doi.org/10.1002/ ecs 2.2019

Hothorn, T., K. Hornik, C. Strobl, and A. Zeileis. 2009. PARTY: a laboratory for recursive partitioning. <http://CRAN.R-project.org/package=party>. Accessed 3 August 2016.

Hothorn T, Hornik K, Zeileis A (2006) Unbiased recursive partitioning: a conditional inference framework. Journal of Computational and Graphical Statistics 15(3):651-674 https://doi.org/10.1198/106186006X133933

Huffman DW, Sánchez Meador AJ, Stoddard MT, Crouse JE, Roccaforte JP (2017) Efficacy of resource objective wildfires for restoration of ponderosa pine (Pinus ponderosa) forests in northern Arizona. Forest Ecology and Management 389(Supplement C):395-403

Jenkins, J.C., D.C. Chojnacky, L.S. Heath, and R.A. Birdsey.. 2004. Comprehensive database of diameter-based biomass regressions for North American tree species. USDA Forest Service General Technical Report NE-319, Northeastern Research Station, Newtown Square, Pennsylvania, USA.

Keeley JE (2009) Fire intensity, fire severity and burn severity: a brief review and suggested usage, International Journal of Wildland Fire. 18:116-126 https:// doi.org/10.1071/WF07049

Key CH, Benson NC (2006) Landscape assessment (LA). Pages LA-1-55. In: Lutes DC, Keane RE, Caratti JF, Key CH, Benson NC, Sutherland S, Gangi L (eds) FIREMON: Fire effects monitoring and inventory system. USDA Forest Service General Technical Report RMRS-GTR-164-CD, Rocky Mountain Research Station, Fort Collins, Colorado, USA

Knapp EE, Lydersen JM, North MP, Collins BM (2017) Efficacy of variable density thinning and prescribed fire for restoring forest heterogeneity to mixed conifer forest in the central Sierra Nevada, CA. Forest Ecology and Management 406:228-241

Knapp EE, Skinner CN, North MP, Estes BL (2013) Long-term overstory and understory change following logging and fire exclusion in a Sierra Nevada mixed-conifer forest. Forest Ecology and Management 310(0):903-914 https://doi.org/10.1016/j.foreco.2013.09.041

Larson AJ, Belote RT, Cansler CA, Parks SA, Dietz MS (2013) Latent resilience in ponderosa pine forest: effects of resumed frequent fire. Ecological Applications 23(6):1243-1249 https://doi.org/10.1890/13-0066.1

Lydersen JM, Collins BM, Brooks ML, Matchett JR, Shive KL, Povak NA, Kane VR, Smith DF (2017) Evidence of fuels management and fire weather influencing fire severity in an extreme fire event. Ecological Applications 27(7):2013-2030 https://doi.org/10.1002/eap.1586

Lydersen JM, Collins BM, Knapp EE, Roller GB, Stephens SL (2015) Relating fuel loads to overstorey structure and composition in a fire-excluded Sierra Nevada mixed conifer forest. International Journal of Wildland Fire 24(4):484494 https://doi.org/10.1071/WF13066

Lydersen JM, Collins BM, Miller JD, Fry DL, Stephens SL (2016) Relating firecaused change in forest structure to remotely sensed estimates of fire severity. Fire Ecology 12(3):99-116 https://doi.org/10.4996/fireecology. 1203099

Lydersen JM, North MP, Knapp EE, Collins BM (2013) Quantifying spatial patterns of tree groups and gaps in mixed-conifer forests: reference conditions and long-term changes following fire suppression and logging. Forest Ecology and Management 304:370-382

Mallek C, Safford H, Viers J, Miller J (2013) Modern departures in fire severity and area vary by forest type, Sierra Nevada and southern Cascades, California, USA. Ecosphere 4(12):art153 https://doi.org/10.1890/ES13-00217.1

Miller, J.D., E.E. Knapp, C.H. Key, C.N. Skinner, C.J. Isbell, R.M. Creasy, and J.W. Sherlock. 2009. Calibration and validation of the Relative differenced Normalized Burn Ratio (RdNBR) to three measures of fire severity in the Sierra Nevada and Klamath Mountains, California, USA. Remote Sensing of Environment 113(3): 645-646 https://doi.org/10.1016/.rse.2008.11.009

Miller JD, Thode AE (2007) Quantifying burn severity in a heterogeneous landscape with a relative version of the delta Normalized Burn Ratio (dNBR). Remote Sensing of Environment 109(1):66-80 https://doi.org/10.1016/j.rse. 2006.12 .006

North M, Collins BM, Safford HD, Stephenson NL (2016) Chapter 27: montane forests. In: Mooney H, Zavaleta E (eds) Ecosystems of California. University of California Press, Berkeley, USA, pp 553-577

North M, Collins BM, Stephens SL (2012) Using fire to increase the scale, benefits and future maintenance of fuels treatments. Journal of Forestry 110(7):392401 https://doi.org/10.5849/jof.12-021

North, M., P.A. Stine, K.L. O'Hara, W.J. Zielinski, and S.L. Stephens. 2009. An ecosystems management strategy for Sierra mixed-conifer forests, with addendum. USDA Forest ServiceGeneral Technical Report PSW-GTR-220, Pacific Southwest Research Station, Albany, California, USA. https://doi.org/10. 2737/PSW-GTR-220

North MP, Stephens SL, Collins BM, Agee JK, Aplet GH, Franklin JF, Fulé PZ (2015) Reform forest fire management. Science 349(6254):1280-1281 https://doi. org/10.1126/science.aab2356

Parks SA, Holsinger LM, Miller C, Nelson CR (2015) Wildland fire as a selfregulating mechanism: the role of previous burns and weather in limiting fire progression. Ecological Applications 25(6):1478-1492 https://doi.org/10. 1890/14-1430.1

Parks SA, Miller C, Nelson CR, Holden ZA (2014) Previous fires moderate burn severity of subsequent wildland fires in two large western US wilderness areas. Ecosystems 17(1):29-42 https://doi.org/10.1007/s10021-013-9704-x

Prichard SJ, Stevens-Rumann CS, Hessburg PF (2017) Tamm review: shifting global fire regimes: lessons from reburns and research needs. Forest Ecology and Management 396(Supplement C):217-233

R Development Core Team. (2014) R: a language and environment for statistical computing. R Foundation for Statistical Computing, Vienna, Austria

Scholl AE, Taylor AH (2010) Fire regimes, forest change, and self-organization in an old-growth mixed-conifer forest, Yosemite National Park, USA. Ecological Applications 20(2):362-380 https://doi.org/10.1890/08-2324.1

Stephens SL, Collins BM, Biber E, Fulé PZ (2016) US federal fire and forest policy: emphasizing resilience in dry forests. Ecosphere 7(11):e01584 https:/doi.org/ 10.1002/ecs2.1584

Stephenson NL (1999) Reference conditions for giant sequoia forest restoration: structure, process, and precision. Ecological Applications. 9(4):1253-1265 https://www.nps.gov/seki/learn/nature/upload/ns_reference.pdf

Stevens-Rumann C, Morgan P (2016) Repeated wildfires alter forest recovery of mixed-conifer ecosystems. Ecological Applications 26(6):1842-1853 https:// doi.org/10.1890/15-1521.1 
Taylor, A.H., A.M. Vandervlugt, R.S. Maxwell, R.M. Beaty, C Airey. and C.N. Skinner 2014. Changes in forest structure, fuels and potential fire behaviour since 1873 in the Lake Tahoe Basin, USA. Applied Vegetation Science 17(1): 17-31 https://doi.org/10.1111/avsc.12049

USDA Forest Service 2018. Fire Effects Information System (FEIS). US Department of Agriculture, Forest Service, Rocky Mountain Research Station, Fire Sciences Laboratory. <https://www.feis-crs.org/feis/faces/index.xhtml>. Accessed 8 January 2018.

Westerling A, Bryant B, Preisler H, Holmes T, Hidalgo H, Das T, Shrestha S (2011) Climate change and growth scenarios for California wildfire. Climatic Change 109(S1):445-463 https://doi.org/10.1007/s10584-011-0329-9

Williams AP, Allen CD, Millar Cl, Swetnam TW, Michaelsen J, Still CJ, Leavitt SW (2010) Forest responses to increasing aridity and warmth in the southwestern United States. Proceedings of the National Academy of Sciences of the United States of America 107(50):21289-21294 https://doi. org/10.1073/pnas.0914211107

Williams AP, Seager R, Abatzoglou JT, Cook Bl, Smerdon JE, Cook ER (2015) Contribution of anthropogenic warming to California drought during 20122014. Geophysical Research Letters 42(16):6819-6828 https://doi.org/10.1002/ 2015GL064924

Zald HSJ, Gray AN, North M, Kern RA (2008) Initial tree regeneration responses to fire and thinning treatments in a Sierra Nevada mixed-conifer forest, USA. Forest Ecology and Management 256(1-2):168-179

\section{Submit your manuscript to a SpringerOpen ${ }^{\circ}$ journal and benefit from:}

- Convenient online submission

- Rigorous peer review

- Open access: articles freely available online

High visibility within the field

- Retaining the copyright to your article

Submit your next manuscript at $\boldsymbol{\nabla}$ springeropen.com 